\title{
Unmasking a subarachnoid hemorrhage
}

Figure $\quad$ MRI performed with face mask shows diffuse bilateral frontal sulcal hyperintensities

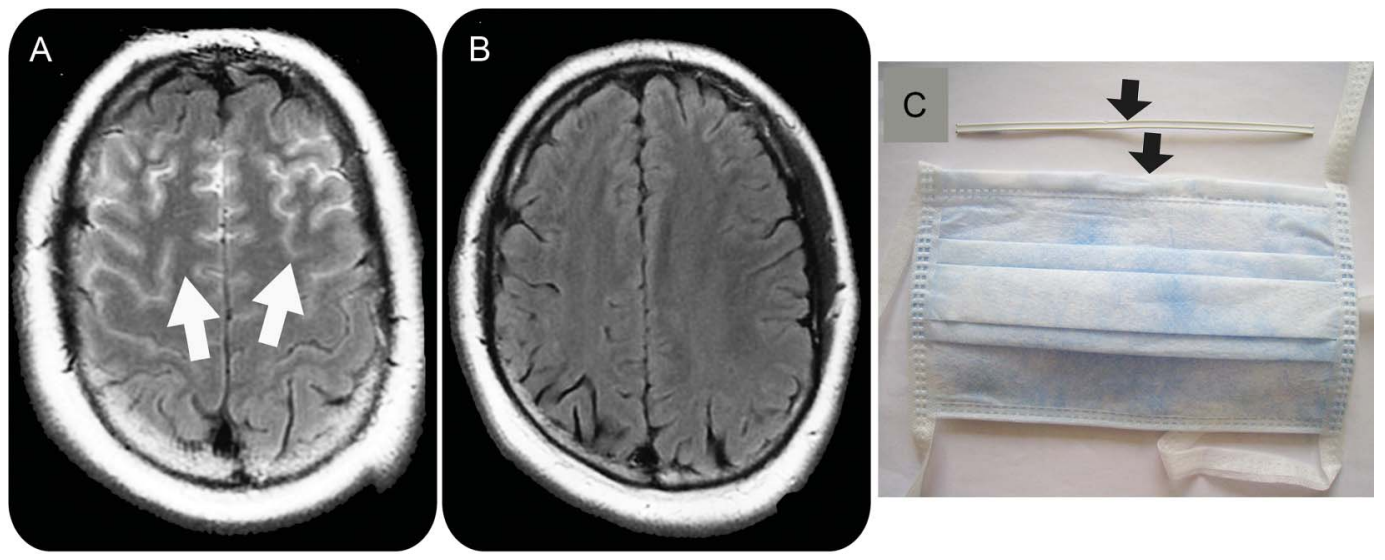

(A) Hyperintensities in fluid-attenuated inversion recovery sequences, disappearing after mask removal (B). (C) The face mask used by our patient, containing a metal part (arrow) in the upper part of the face mask, probably responsible for the susceptibility artifact.

A 53-year-old patient presented with acute headache. CT and intra/extracranial CT angiography were normal. A traumatic lumbar puncture showed 8,500 erythrocytes $/ \mathrm{mm}^{3}$ and 24 leukocytes $/ \mathrm{mm}^{3}$. MRI showed extensive sulcal fluid-attenuated inversion recovery (FLAIR) hyperintensities suggesting subarachnoid hemorrhage (figure). However, since $\mathrm{T} 2^{*}$-weighted sequences were normal and the patient was wearing a face mask (for a possible meningeal infection), a radiologic artifact was suspected. Immediately after, MRI without face mask showed absence of FLAIR abnormalities, confirming the suspected susceptibility artifact probably caused by the metal part of the face mask.

Other artifact-related causes of subarachnoid FLAIR hyperintensities include CSF flow, vascular pulsation, motion artefact, and supplemental oxygen. ${ }^{1}$

Giovanni Castelnovo, MD, Dimitri Renard, $M D$

From the CHU Nîmes, Hôpital Caremeau, Nîmes, France.

Author contributions: Giovanni Castelnovo: drafting/revising the manuscript, study concept or design, analysis or interpretation of data, acquisition of data. Dimitri Renard: drafting/revising the manuscript, study concept or design, analysis or interpretation of data, acquisition of data, study supervision.

Study funding: No targeted funding reported.

Disclosure: The authors report no disclosures relevant to the manuscript. Go to Neurology.org for full disclosures.

Correspondence to Dr. Castelnovo: giovanni.castelnovo@chu-nimes.fr

1. Stuckey SL, Goh TD, Heffernan T, Rowan D. Hyperintensity in the subarachnoid space on FLAIR MRI. AJR Am J Roentgenol 2007;189:913-921. 


\title{
Neurology
}

\author{
Unmasking a subarachnoid hemorrhage \\ Giovanni Castelnovo and Dimitri Renard \\ Neurology 2013;80;2274 \\ DOI 10.1212/WNL.0b013e318296e9e5
}

This information is current as of June 10, 2013

$\begin{array}{ll}\begin{array}{l}\text { Updated Information \& } \\ \text { Services }\end{array} & \begin{array}{l}\text { including high resolution figures, can be found at: } \\ \text { http://n.neurology.org/content/80/24/2274.full }\end{array} \\ \text { References } & \text { This article cites } 1 \text { articles, } 0 \text { of which you can access for free at: } \\ & \text { http://n.neurology.org/content/80/24/2274.full\#ref-list-1 } \\ \text { Subspecialty Collections } & \text { This article, along with others on similar topics, appears in the } \\ & \text { following collection(s): } \\ & \text { All Headache } \\ \text { http://n.neurology.org/cgi/collection/all_headache } & \text { MRI } \\ & \text { http://n.neurology.org/cgi/collection/mri } \\ & \text { Subarachnoid hemorrhage } \\ & \text { http://n.neurology.org/cgi/collection/subarachnoid_hemorrhage } \\ & \text { Information about reproducing this article in parts (figures,tables) or in } \\ & \text { its entirety can be found online at: } \\ \text { http://www.neurology.org/about/about_the_journal\#permissions } & \text { Information about ordering reprints can be found online: } \\ \text { Permissions \& Licensing } & \text { http://n.neurology.org/subscribers/advertise }\end{array}$

Neurology ${ }^{\circledR}$ is the official journal of the American Academy of Neurology. Published continuously since 1951, it is now a weekly with 48 issues per year. Copyright (C 2013 American Academy of Neurology. All rights reserved. Print ISSN: 0028-3878. Online ISSN: 1526-632X.

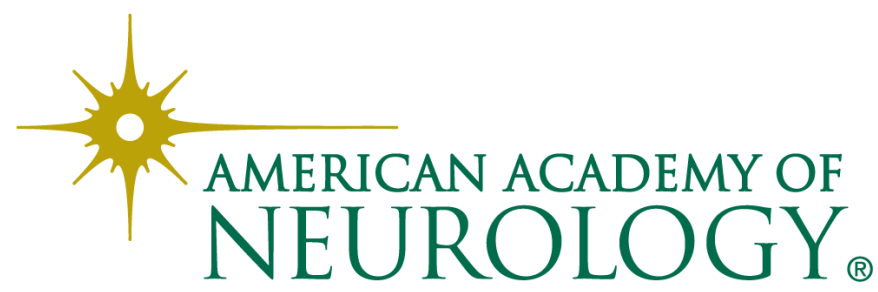

